\title{
Menelusur Ketimpangan Distribusi Pendapatan Kabupaten dan Kota Jurnal Ecces
}

\author{
Andi Samsir ${ }^{1}$ \\ Abdul Rahman ${ }^{2}$ \\ ${ }^{1}$ Program Studi Ekonomi Pembangunan \\ Fakultas Ekonomi Universitas Negeri Makassar \\ Jl. Andi Pangerang Pettarani 90222 (Kampus Gunung Sari) \\ ${ }^{2}$ Program Studi Ilmu Ekonomi \\ Fakultas Ekonomi dan Bisnis Islam Universitas Islam Negeri Alauddin Makassar \\ Jl. Yasin Limpo, No. 36 Samata, Gowa Sulawesi Selatan \\ E-mail :syamsir_fe03unm@yahoo.co.id ${ }^{1}$, abdulrahman1582@gmail.com²
}

\section{Abstrak: Menelusur Ketimpangan Distribusi Pendapatan Kabupaten dan \\ Kota}

Provinsi Sulawesi Selatan merupakan provinsi dengan output (PDRB) terbesar. Namun disaat yang sama, distribusi pendapatan di Sulawesi Selatan justru semakin timpang. Dilihat dari gini ratio, berada pada ketimpangan yang cukup mengkhawatirkan. Penelitian ini bertujuan mengetahui pengaruh desentralisasi fiskal, aglomerasi, tingkat pengganguran terbuka, Indeks Pembangunan Manusia dan jumlah penduduk terhadap disparitas distribusi pendapatan di kabupaten/kota Provinsi Sulawesi Selatan. Analisis data menggunakan regresi panel dengan data time series selama 6 tahun dan data cross section 24 kabupaten/kota di Provinsi Sulawesi Selatan. Hasil penelitian ini menunjukkan selama periode penelitian 20102015, terjadi ketimpangan pembangunan yang tidak cukup signifikan berdasarkan Indeks Williamson, sedangkan menurut Indeks entropi Theil, ketimpangan pembangunan boleh dikatakan kecil yang berarti masih terjadinya pemerataan pembangunan setiap tahunnya selama periode pengamatan. Sebagai akibatnya tidak terbuktinya hipotesis Kuznets di Kabupaten/kota Provinsi Sulawesi Selatan yang mengatakan adanya kurva U terbalik. Variabel desentralisasi fiskal, aglomerasi, tingkat pengangguran terbuka, Indeks Pembangunan Manusia, dan jumlah penduduk, secara simultan berpengaruh terhadap disparitas distribusi pendapatan antar kabupaten/kota di Provinsi Sulawesi Selatan. Desentralisasi fiskal dan aglomerasi tidak berpengaruh signifikan, sedangkan tingkat pengangguran terbuka, Indeks Pembangunan Manusia dan jumlah penduduk berpengaruh signifikan terhadap disparitas distribusi pendapatan antar kabupaten/kota di Provinsi Sulawesi Selatan.

Kata Kunci: Desentralisasi fiskal, Aglomerasi, Tingkat Pengganguran Terbuka, Indeks Pembangunan Manusia dan Jumlah Penduduk 


\section{Abstract: In Search Disparity of Income Distribution of District and City}

South Sulawesi province is the province with the largest output (GDP). But at the same time, the distribution of income in South Sulawesi is even more unbalanced, as seen from the Gini Ratio is at a quite alarming imbalance. This study aims to determine the effect of fiscal decentralization, agglomeration, open unemployment rate, Human Development Index and population to income distribution disparity in regencies / cities South Sulawesi Province. Data analysis using panel regression with time series data for 6 years and cross section data 24 regency / city in South Sulawesi Province. The results of this study show that during the period of 2010-2015, there is a significant inequality of development based on Williamson Index, whereas according to Theil entropy index, the imbalance of development is small, meaning that there is still equitable development every year during the observation period. As a result the Kuznets hypothesis is not proven in the regency / municipality of South Sulawesi Province which says there is an inverted $U$ curve. Variables of fiscal decentralization, agglomeration, open unemployment rate, Human Development Index, and population, simultaneously affect the income distribution disparity between districts / cities in South Sulawesi Province. Fiscal and agglomeration decentralization has no significant effect, while the open unemployment rate, Human Development Index and the number of population significantly influence the income distribution disparity between regencies / cities in South Sulawesi Province.

Keywords: Fiscal Decentralization, Agglomeration, Open Unemployment Rate, Human Development Index, Population.

\section{PENDAHULUAN / INTRODUCTION}

Provinsi Sulawesi Selatan berperan penting sebagai pintu gerbang Kawasan Timur Indonesia. Kinerja perekonomian Sulawesi Selatan periode tahun 2006-2014 cukup baik dengan laju pertumbuhan rata-rata 7,36 persen. Angka ini lebih tinggi dari laju pertumbuhan ekonomi nasional sebesar 5,90 persen pada periode yang sama. Di tingkat wilayah, Provinsi Sulawesi Selatan merupakan provinsi dengan output (PDRB) terbesar karena pada tahun 2013 telah berkontribusi sebesar 49,97 persen terhadap pembentukan PDRB Wilayah Sulawesi dan 2,37 persen terhadap pembentukan PDB nasional. Peran Provinsi Sulawesi Selatan sangat strategis dalam mendukung Pulau Sulawesi sebagai pusat produksi dan pengolahan hasil pertanian, perkebunan, perikanan, serta pertambangan nikel khususnya sebagai simpul pertanian pangan, simpul perikanan, dan klaster industri. Selain itu, Provinsi Sulawesi Selatan memiliki pelabuhan internasional yang semakin meningkatkan posisi strategisnya. 
Namun disisi lain distribusi pendapatan di Sulawesi Selatan masih timpang. Dilihat dari Gini Ratio berada pada ketimpangan yang cukup mengkhawatirkan. Pertumbuhan ekonomi sangatlah penting untuk dijaga oleh berbagai kebijakan daerah maupun pusat. Pertumbuhan ekonomi pun diharapkan bisa berkualitas yang artinya pertumbuhannya diperoleh dari semua kegiatan ekonomi dan terutama banyak digeluti oleh masyarakat secara luas. Bukan hanya terjadi pada aktivitas padat modal atau dari sektor yang tidak berdampak luas pada penyerapan tenaga kerja. Melihat pada sebaran 24 kabupaten/kota, di mana kota Makassar sebagai pusat pertumbuhan atau kolektor dan distributor Indonesia Timur, belum mampu menciptakan difusi kemajuan di wilayahnya. Sulawesi Selatan masih menyisakan banyak Kabupaten daerah tertinggal dengan jumlah yang besar yaitu 13 Kabupaten dari total 24 Kabupaten/kota yang ada di Sulawesi Selatan. Sulawesi Selatan merupakan provinsi yang memiliki potensi yang besar untuk berkembang dan diharapkan dapat mendorong perkembangan daerah-daerah di sekitarnya khususnya Kawasan Timur Indonesia.

Menurut Simon Kuznets mengemukakan bahwa pada tahap awal-awal pertumbuhan ekonomi, distribusi pendapatan memburuk sehingga ketimpangan tinggi. Namun pada tahap-tahap selanjutnya akan membaik. Hipotesis ini dikenal dengan hipotesis "U. Terbalik" Kuznet. Menurut Kuznet distribusi pendapatan akan meningkat sejalan dengan pertumbuhan ekonomi. Sesuai dengan rangkaian dari perubahan kecenderungan distribusi pendapatan dengan ukuran koefisien Gini dan pertumbuhan PDB perkapita yang akan terlihat seperti kurva yang berbentuk seperti huruf $U$ terbalik.

Besarnya PDRB antar Kabupaten/kota di Sulawesi Selatan cukup bervariasi. Hal ini disebabkan setiap daerah memiliki keunggulan komparatif yang berbeda, seperti perbedaan tersedianya sumber daya alam, faktor-faktor produksi, infrastruktur penunjangnya dan kemampuan sumber daya manusia yang dimiliki wilayah tersebut. Perbedaan ini mengakibatkan besarnya (size) PDRB di setiap daerah/wilayah berbeda cukup besar, hal ini di gambarkan dengan kontribusinya terhadap total PDRB yang berbeda. Selain itu, tinggi pasokannya terhadap PDRB Sulawesi Selatan ternyata tidak sejalan dengan pendapatan perkapitanya, dimana PDRB perkapita tertinggi ada di kabupaten Luwu Timur.

Menurut Hirschman dalam Kuncoro (2004), perbedaan antar wilayah tersebut yang menjadi hambatan dalam pemerataan pembangunan ekonomi dikarenakan terkonsentrasinya suatu kegiatan perekonomian yang berdampak pada meningkatnya pertumbuhan ekonomi dibeberapa wilayah yang memiliki sumber daya alam melimpah. Kekayaan alam yang dimiliki seharusnya dapat menjadi nilai tambah dalam meningkatkan 
pembangunan ekonomi. Kelebihan yang dimiliki tersebut diharapkan dapat memberikan dampak menyebar (spread effect). Namun kekayaan alam ini, tidak dimiliki oleh semua daerah di seluruh Indonesia secara merata. Keadaan seperti itulah yang menyebabkan timbulnya ketimpangan antar daerah.

Selain itu, untuk membiayai pembangunan memerlukan dana yang tidak sedikit. Dana untuk pembiayaan pembangunan daerah terutama digali dari sumber kemampuan sendiri dengan prinsip peningkatan kemandirian dalam pelaksanaan pembangunan. Dengan kata lain pemerintah daerah dipacu untuk meningkatkan kemampuan seoptimal mungkin di dalam membelanjai urusan rumah tangga sendiri, dengan cara menggali segala sumber dana yang potensial yang ada di daerah tersebut. Dalam hubungan ini pengelolaan APBD terus disempurnakan agar dapat menghimpun dana yang cukup untuk membiayai pembangunan.

Apabila ditinjau secara khusus jumlah penduduk Sulawesi Selatan berdasarkan BPS tahun 2015 berjumlah 8.520.304 jiwa yang tersebar di 23 kabupaten/kota, dengan jumlah penduduk terbesar 1.449.401 jiwa yang mendiami kota Makasar. Sebagian besar penduduk Sulawesi Selatan terkosentrasi pada daerah pada daerah yang lebih dulu berkembang di bandingkan dengan daerah lainnya. Langkah dan upaya pemerintah dalam menggalakkan otonomisasi daerah di tingkat Kabupaten/Kota pada hakekatnya adalah untuk mendorong gerak roda pembangunan di daerah yaitu melalui optimalisasi kinerja pemerintah daerah, yang pada akhirnya lebih mendorong pertumbuhan perekonomian daerah menuju peningkatan kesejahteraan masyarakat. Dengan demikian, adapun tujuan penelitian ini adalah 1) membuktikan hipotesis Kuznets berlaku di Provinsi Sulawesi Selatan; 2) mengetahui dan menganalisis pengaruh desentralisasi fiskal, aglomerasi, tingkat pengganguran terbuka, Indeks Pembangunan Manusia dan jumlah penduduk terhadap disparitas distribusi pendapatan di kabupaten/kota Provinsi Sulawesi Selatan. 


\section{TINJAUAN TEORITIK / LITERATURE REVIEW}

\section{Konsep Ketimpangan Distribusi Pendapatan}

Ketimpangan pendapatan adalah suatu kondisi dimana distribusi pendapatan yang diterima masyarakat tidak merata. Ketimpangan ditentukan oleh tingkat pembangunan, heterogenitas etnis, ketimpangan juga berkaitan dengan kediktatoran dan pemerintah yang gagal menghargai property rights. Ketimpangan harus mendapat perhatian karena ketimpangan wilayah yang ekstrim menyebabkan inefisiensi ekonomi, alokasi aset yang tidak efisien dan menambah jumlah kemiskinan, inefisiensi, melemahkan stabilitas sosial dan solidaritas dan memperkuat kekuatan politis golongan kaya sehingga menimbulkan ketidakadilan bagi masyarakat. Ketimpangan pendapatan akan menghambat pertumbuhan. Ketimpangan menyebabkan kebijakan redistribusi pendapatan yang tentunya akan mahal. Todaro, Glaeser (2006), Alesina dan Rodrik (1994) dan Hajiji, (2010).

Namun, pandangan itu ditentang berdasarkan temuan Ismoro (1995) dalam (Rahayu, 2000) dan (Todaro, 2000) bahwa distribusi pendapatan dapat berwujud pemerataan maupun ketimpangan, yang menggambarkan tingkat pembagian pendapatan yang dihasilkan oleh berbagai kegiatan ekonomi. Distribusi dari suatu proses produksi terjadi setelah diperoleh pendapatan dari kegiatan usaha. Distribusi pendapatan mencerminkan ketimpangan atau meratanya hasil pembangunan suatu daerah atau negara, baik yang diterima masing-masing orang ataupun dari kepemilikan faktor-faktor produksi dikalangan penduduknya. Distribusi pendapatan yang didasarkan pada pemilik faktor produksi ini akan berkaitan dengan proses pertumbuhan pendapatan, adapun pertumbuhan pendapatan dalam masyarakat yang didasarkan pada kepemilikan faktor produksi.

\section{Faktor-Faktor Penyebab Ketimpangan Pendapatan}

Ada dua argumen yang berhubungan dengan masalah pembangunan ekonomi dengan pemerataan, yakni pandangan antara mashab pertumbuhan versus mashab pemerataan (Todaro, 2000). Argumen tradisional menfokuskan lebih di dalam pengelolaan faktor-faktor produksi, tabungan dan pertumbuhan ekonomi. Distribusi pendapatan yang sangat tidak merata merupakan sesuatu yang terpaksa dikorbankan demi memacu laju pertumbuhan ekonomi secara cepat. Akibat dari pengaruh teori dan kebijakan perekonomian pasar bebas, penerimaan pemikiran seperti itu oleh kalangan ekonom pada umumnya dari negara-negara maju maupun negara-negara berkembang, baik secara implisit maupun eksplisit menunjukan bahwa mereka tidak begitu memperhatikan pentingnya masalah kemiskinan dan ketimpangan distribusi pendapatan. 
Namun hal itu ditentang oleh banyak ekonom pembangunan, yang merasa bahwa pemerataan pendapatan yang lebih adil di negara-negara berkembang tidak bisa di nomor duakan, karena hal itu merupakan suatu kondisi penting atau syarat yang harus diadakan guna menunjang pertumbuhan ekonomi (Todaro, 2000). Dalam argumen tandingan tersebut terdapat lima alasan yaitu;

Pertama, ketimpangan yang begitu besar dan kemiskinan yang begitu luas telah menciptakan kondisi sedemikian rupa sehingga masyarakat miskin tidak memiliki akses terhadap perolehan kredit. Berbagai faktor ini secara bersama-sama menjadi penyebab rendahnya pertumbuhan GNP per kapita dibandingkan jika terdapat pemerataan pendapatan yang lebih besar.

Kedua, berdasarkan observasi sekilas yang ditunjang oleh data-data empiris yang ada, kita mengetahui bahwa tidak seperti yang terjadi dalam sejarah pertumbuhan ekonomi negara-negara maju, orang-orang kaya di negara-negara dunia ketiga tidak dapat diharapkan kemampuan atau kesediaannya untuk menabung dan menanamkan modalnya dalam perekonomian domestik.

Ketiga, rendahnya pendapatan dan taraf hidup kaum miskin yang berwujud berupa kondisi kesehatannya yang buruk, kurang makan dan gizi dan pendidikannya yang rendah justru akan menurunkan produktivitas ekonomi mereka dan pada akhirnya mengakibatkan rendahnya pertumbuhan ekonomi nasional secara keseluruhan.

Keempat, upaya-upaya untuk menaikkan tingkat pendapatan penduduk miskin, akan merangsang meningkatkannya permintaan terhadap barang-barang produksi dalam negeri seperti bahan makanan dan pakaian.

Kelima, dengan tercapainya distribusi pendapatan yang lebih adil melalui upayaupaya pengurangan kemiskinan masyarakat, maka akan segera tercipta banyak insentif atau rangsangan-rangsangan materiil, dan psikologis yang pada gilirannya akan menjadi penghambat kemajuan ekonomi. Dengan demikian dapat disimpulkan bahwa promosi pertumbuhan ekonomi secara cepat dan upaya-upaya pengentasan kemiskinan serta penanggulangan ketimpangan pendapatan bukanlah tujuan-tujuan yang saling bertentangan sehingga yang satu tidak perlu diutamakan dengan mengorbankan yang lain.

Menurut Myrdal (1957), perbedaan tingkat kemajuan ekonomi antar daerah yang berlebihan akan menyebabkan pengaruh yang merugikan (backwash effects) mendominasi pengaruh yang menguntungkan (spread effects) terhadap pertumbuhan daerah, dalam hal ini mengakibatkan proses ketidakseimbangan. Pelaku-pelaku yang mempunyai kekuatan di pasar secara normal akan cenderung meningkat bukannya menurun, sehingga 
mengakibatkan ketimpangan antar daerah (Arsyad, 2004). Studi yang menganalisis faktorfaktor penyebab ketimpangan ekonomi antarprovinsi atau wilayah di Indonesia, diantaranya Esmara (1975), Soediono dan Igusa (1992), Azis (1989), Hill dan Williams (1989), Sondakh (1994), Ibrahim (1974), Uppal dan Handoko (1988), Arsyad (1999) Akita dan Lukman (1999), Safrizal (1999, 2000) dan Manik (2009) dalam Timbunan menyimpulkan faktorfaktor penyebab ketimpangan pembangunan antar wilayah yaitu : 1) Perbedaan Kandungan Sumber Daya Alam; 2) Perbedaan Kondisi Demografis; 3) Kurang Lancarnya Mobilitas Barang dan Jasa; 4) Konsentrasi Kegiatan Ekonomi Daerah dan 5) Alokasi Dana Pembangunan Antar Daerah.

\section{METODE PENELITIAN / METHODS}

Penelitian ini menggunakan metode pendekatan kuantitatif, yaitu penelitian berupa angka-angka dan analisis bersifat statistik dengan tujuan untuk menguji hipotesis yang telah ditetapkan (Sugiyono, 2013). Berdasarkan tingkat ekplanasi, penelitian ini merupakan penelitian asosiatif yaitu penelitian yang bertujuan untuk menguji dan menganalisis pengaruh pertumbuhan ekonomi, desentralisasi fiskal, aglomerasi dan tingkat Pengganguran Terbuka terhadap Disparitas distribusi pendapatan kabupaten/kota di Provinsi Sulawesi Selatan. Analisis data menggunakan regresi panel dengan data time series selama 6 tahun dan data cross section 24 kabupaten/kota di Provinsi Sulawesi Selatan, sehingga observasi berjumlah 144 buah.

Jenis data yang digunakan adalah data sekunder yang berupa data panel, yaitu gabungan dari data time series dari tahun 2010-2015 (6 tahun) dan data cross section dari 24 Kabupaten/kota di provinsi di Sulawesi Selatan. Data diperoleh dari Badan Pusat Statistik Provinsi Sulawesi Selatan, Badan Promosi dan Penanaman Modal Daerah Provinsi Sulawesi Selatan serta sumber lain yang terkait dengan penelitian ini. Secara rinci data yang dipergunakan yakni PDRB atas dasar harga konstan 2010, PDRB per kapita atas dasar harga konstan 2010, Jumlah penduduk, Pendapatan Asli Daerah dan total penerimaan daerah dan data jumlah pengangguran dan angkatan kerja baik di tingkat Provinsi Sulawesi Selatan maupun di tingkat Kabupaten/kota tahun 2010 - 2015.

Teknik analisis yang digunakan dalam penelitian ini adalah analisis statistik deskriptif dan analisis regresi. Statistik deskriptif digunakan untuk menjawab pertanyaan penelitian pertama dan kedua yakni perhitungan tingkat disparitas distribusi pendapatan menggunakan pendekatan PDRB per kapita relatif dan pembuktian hipotesis Kuznets dijelaskan melalui 
gambar dan korelasi Pearson. Sedangkan analisis regresi dilakukan dengan metode Ordinary Least Square (OLS) menggunakan Program Eviews 9. Data yang digunakan dalam analisis ini berupa data time-series. model persamaannya sebagai berikut :

$$
\begin{aligned}
& Y=\beta_{0}+\beta_{1} X_{1}+e_{t} \quad ; t=1,2, \ldots, T \\
& \text { Di mana } T \text { adalah banyak data time-series. }
\end{aligned}
$$

\section{Estimasi Model regresi}

Analisis pengaruh pertumbuhan ekonomi, Desentralisasi Fiskal, Aglomerasi, dan Tingkat Pengganguran Terbuka terhadap ketimpangan distribusi pendapatan menggunakan data time series selama 6 (enam) tahun yang diwakili data tahunan dari 2010-2015 yang menghasilkan 6 observasi. Model dasar ketimpangan wilayah dalam penelitian ini sebagai berikut :

$R D=f(D F, A g, T P T, I P M, N P$

Model dasar tersebut akan diturunkan menjadi model ekonometrik sebagai berikut : $R D_{t}=a_{1}+a_{2} D F_{t}+a_{3} A g_{t}+a_{4} T P T_{t}+a_{5} I P M_{t}+a_{6} N P_{t}+e_{t}$

Dimana t menunjukan time series (periode waktu).

Dalam Sjafrizal (2008) dijelaskan karena hubungan antara disparitas wilayah dengan tingkat disparitas regional dengan tingkat pembangunan ekonomi tidaklah linear, maka persamaan regresi dapat pula dilakukan dalam bentuk fungsi non linear. Dengan demikian persamaan yang dapat digunakan untuk mengetahui faktor penentu ketimpangan antar wilayah adalah sebagai berikut:

$\mathrm{RD}=\mathrm{a}_{1} \mathrm{DF}^{\mathrm{a} 2} \mathrm{Ag}^{\mathrm{a} 3} \mathrm{TPT}^{\mathrm{a} 4} \mathrm{IPM}^{\mathrm{a} 4} \mathrm{NP}^{\mathrm{a} 5}$

Persamaan ini akan dapat dihitung dengan metode regresi setelah dilakukan transformasi dengan menggunakan logaritma sehingga dapat diformulasikan sebagai berikut:

Log $R_{t} \quad=a_{1}+a_{2} D F+a_{3} A g+a_{4} T P T++a_{5} I P M+a_{6} N P+e_{t}$

1. Uji Spesifikasi Model

Pengujian Spesifikasi Model dilakukan dengan Uji Hausman. Uji Hausman digunakan untuk memilih model terbaik apakah Fixed Effect Model (FEM) atau Random Effect Model (REM). Hipotesis nolnya adalah bahwa model yang tepat untuk regresi data panel adalah model Random Effect dan hipotesis alternatifnya adalah model yang tepat untuk regresi data panel adalah model Fixed Effect Model.

Apabila nilai probabilitas Hausman lebih kecil dari taraf signifikansi 0,05 maka hipotesis nol ditolak yang artinya model yang tepat untuk regresi data panel adalah model Fixed Effect Model, begitu juga sebaliknya. 
2. Uji Asumsi Klasik

Seperti yang sudah dijelaskan sebelumnya, sebelum melakukan analisis maka harus dilakukan uji asumsi klasik terlebih dahulu untuk menghilangkan bias dari data-data yang digunakan dalam suatu penelitian. Uji asumsi klasik ini terdiri dari empat uji yang akan dilakukan. Keempat uji tersebut antara lain adalah sebagai berikut:

3. Uji Hipotesis

a. Uji hipotesis secara serentak (simultan), Uji Hipotesis ini menggunakan uji F (Ftest) dimana nilai $\mathrm{F}$-test dibandingkan dengan nilai $\mathrm{F}$ tabel pada tingkat keyakinan tertentu. Dari uji F selanjutnya akan diputuskan menerima atau menolak hipotesis. Adapun uji statistik F adalah sebagai berikut:

$$
\mathrm{F}=\frac{\mathrm{R}^{2} / \mathrm{k}}{\left(1-\mathrm{R}^{2}\right)(\mathrm{n}-\mathrm{k}-1)}
$$

Apabila nilai $F$ hitung lebih besar dari nilai $F$ tabel maka Hipotesis nol yang di terima berarti signifikan $\left(\mathrm{H}_{1}\right)$

b. Uji hipotesis secara parsial, Uji Hipotesis ini menggunakan uji t (t-test), dimana nilai t-test dibandingkan dengan nilai t tabel pada tingkat keyakinan tertentu. Adapun uji statistik $t$ adalah sebagai berikut:

$\mathrm{t}=\frac{\beta_{1-\beta_{1}}}{\operatorname{Sn}\left(\beta_{1}\right)}$

Hipotesis nol ditolak apabila nilai $\mathrm{t}$ tabel lebih besar daripada $\mathrm{t}$ hitung dan sebaliknya apabila nilai $\mathrm{t}$ tabel lebih kecil dari nilai $\mathrm{t}$ hitung maka hipotesis nol diterima. Sedangkan untuk menguji keeratan hubungan antar variabel maka akan dilihat nilai koefisien korelasi parsial $\left(r^{2}\right)$ dan koefisien determinasi $\left(R^{2}\right)$. Nilai koefisien korelasi partial mencerminkan kemampuan variabel bebas dalam menjelaskan variasi atau perubahan variabel terikat. Sedangkan koefisien determinasi mencerminkan kemampuan variabel-variabel bebas secara serentak dalam menjelaskan variasi atau perubahan dari variabel terikat.

\section{c. Koefisien Determinasi $\left(\mathbf{R}^{2}\right)$}

Koefisien determinasi $\left(R^{2}\right)$ dimaksudkan untuk mengetahui tingkat ketepatan paling baik dalam analisa regresi dimana hal yang ditunjukan oleh besarnya koefisien determinasi $\left(R^{2}\right)$ antara 0 (nol) dan I (satu). Koefsien determinasi $\left(R^{2}\right)$ nol variabel independen sama sekali tidak berpengaruh terhadap variabel dependen. Apabila koefisien determinasi semakin mendekati satu, maka dapat dikatakan bahwa variabel independen berpengaruh terhadap variabel dependen. 


\section{HASIL DAN PEMBAHASAN / DISCUSSION}

\section{A. Pembuktian Hipotesis Kuznets}

Dari gambar 1 dan 2 dapat diketahui Indeks Williamson maupun Indeks entropi Theil yang menunjukkan kecenderungan disparitas distribusi pendapatan di Kabupaten/Kota di Provinsi Sulawesi Selatan dalam periode tahun 2010-2015. Akan tetapi kecendrungan tersebut belum tentu dapat membuktikan hipotesis Kuznets di Provinsi Sulawesi Selatan berlaku.

Hipotesis Kuznets dapat dibuktikan dengan cara membuat grafik antara pertumbuhan ekonomi dengan angka indeks ketimpangan baik Indeks Williamson maupun Indeks entropi Theil. Grafik tersebut menggambarkan hubungan antara pertumbuhan PDRB dengan indeks ketimpangan Williamson maupun pertumbuhan PDRB dengan indeks ketimpangan entropi Theil pada periode 2010-2015.

Gambar 1 Kurva Hubungan antara Indeks Williamson dengan Pertumbuhan ekonomi Provinsi Sulawesi Selatan Periode 2010-2015

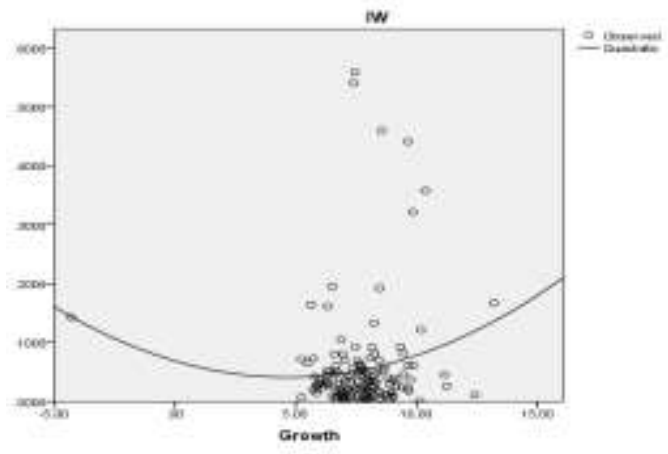

Sumber: Data Diolah, Tahun 2017

Gambar 2 Kurva Hubungan antara Indeks entropi Theil dengan PDRB Provinsi Provinsi Sulawesi Selatan Periode 2010-2015

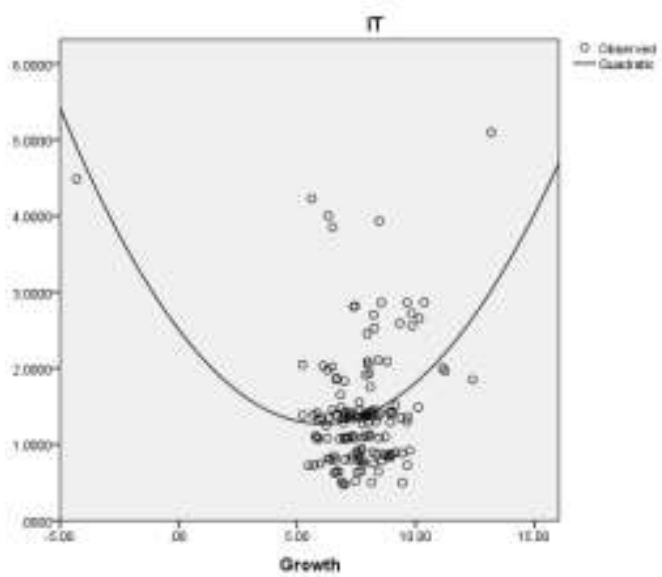

Sumber: Data Diolah, Tahun 2017 
Selain menggunakan gambaran kurva, peneliti juga menggunakan gambaran secara statistik yakni melalui pengolahan data statistik melalui korelasi Pearson untuk mengetahui hubungan antara PDRB dengan Indeks Williamson dan antara PDRB dengan Indeks Entropi Theil.

Dari hasil analisis korelasi Pearson antara PDRB dengan Indeks Williamson terdapat nilai $-0,997$ dengan tingkat signifikasi 0,23 dan korelasi antara PDRB dengan Indeks entropi Theil dengan nilai 0,982 dan signifikasi 0,61 yang berarti secara statistik korelasi ini kurang kuat karena tidak terbukti secara signifikasi pada $a=5 \%$.

Tabel 1 Korelasi Pearson antara Pertumbuhan Ekonomi dengan Indeks Williamson dan Indeks entropi Theil

\begin{tabular}{lcc}
\hline \multicolumn{1}{c}{ Uraian } & Signifikansi & Nilai Kofisien \\
\hline Indeks Williamson & 0.438 & 0.065 \\
Indeks entropi Theil & 0.971 & -0.003 \\
\hline
\end{tabular}

Sumber: Data Diolah, Tahun 2017

\section{B. Estimasi Model}

Tabel 2 Hasil Uji Hausman

Correlated Random Effects - Hausman Test

Equation: Untitled

Test cross-section random effects

\begin{tabular}{lccc}
\hline Test Summary & Chi-Sq. Statistic & Chi-Sq. d.f. & Prob. \\
Cross-section random & 9.891531 & 5 & 0.0284 \\
\hline
\end{tabular}

Sumber: Lampiran (Diolah), Tahun 2017

Dari hasil hausman test di atas menunjukkan bahwa nilai probabilititasnya 0.0284 lebih kecil dari tingkat signifikasi 0,05. Sehigga dengan demikian hipotesis nol di tolak dan model yang digunakan fixed effect

1. Pengujian Asumsi Klasik

Hasil uji normalitas dengan melihat nilai Jarque Bera dihitung dengan nilai probabilitasnya. Dimana jika probabilitasnya lebih besar dari alpha 0,05 maka uji normalitas diterima atau dengan kata lain bahwa residul ut terdistribusi normal.

Uji Heterokedastisitas 
Untuk mendekteksi apakah tidaknya heteroskedastisitas dengan cross section weights dengan membandingkan nilai Sum squared resid. Diketahui bahwa di dalam model empiris pada kasus analisis disparitas pendapatan di Provinsi Sulawesi Selatan tidak terdapat masalah Heteroskedastisitas Karena nilai Sum Squaered resid pada unweinghted statistic > Sum Squared resid weighted statistic yaitu sebesar $84.25779>70.55774$

a. Uji Multikolinearitas

Dengan menggunakan cara melihat koefisien korelasi antar variabel. Apabila koefisien korelasi di bawah angka 0,8 maka dapat dikatakan tidak terdapat multikolinearitas sempurna. Tabel 3 menunjukkan bahwa koefisien korelasi antar variabel di bawah 0,8 sehingga dapat disimpulkan tidak terjadi multikolinearitas pada model penelitian.

Tabel 3 Koefisien Korelasi Antar Variabel

\begin{tabular}{|c|c|c|c|c|c|}
\hline Variabel & $\mathrm{DF}(\mathrm{X} 1)$ & $\mathrm{DF}(\mathrm{X} 2)$ & TPT (X3) & IPM (X4) & NP (X5) \\
\hline$A G$ & 0.754 & 1.000 & 0.428 & 0.548 & 0.896 \\
\hline DF & 1.000 & 0.754 & 0.373 & 0.732 & 0.622 \\
\hline IPM & 0.732 & 0.548 & 0.463 & 1.000 & 0.319 \\
\hline NP & 0.622 & 0.896 & 0.275 & 0.319 & 1.000 \\
\hline TPT & 0.373 & 0.428 & 1.000 & 0.463 & 0.275 \\
\hline
\end{tabular}

Sumber: Data diolah, Tahun 2017

Dari tabel 3 terlihat bahwa $R^{2}$ regresi model utama lebih kecil daripada nilai $R^{2}$ regresi parsialnya, maka dapat ditarik kesimpulan bahwa model yang diestimasi terkena masalah multikolinearitas. Masalah multikolinearitas adalah terjadinya hubungan linear diantara beberapa atau semua variabel bebas yang memang biasanya terjadi pada penilitian data runtut waktu. Sebenarnya multikolenearitas dimungkinkan dapat sedikit diobati dengan menambah data, namun pada model ini terdapat keterbatasan data yang tersedia sehingga tidak dapat menambah atau memperpangjang skala tahun penelitian.

b. Uji Autokolerasi

Dari hasil estimasi didapat nilai D-W statistik sebesar 1.424 pada dengan jumlah sampel 144, dan jumlah variabel bebas 5 didapat nilai du sebesar 1.756, dl sebesar 1.592, dan 4-du sebesar 2.244, berarti didapati du< d < 4-du yang artinya tidak terdapat autokolerasi dalam model.

2. Pengujian Statistik Analisis Regresi

a. Koefisien Determinasi $\left(R^{2}\right)$ 
Koefisien determinasi $\left(R^{2}\right)$ mengukur seberapa besar kemampuan variable independen dalam menjelaskan variabel dependen. Nilai koefisien determinasi adalah nol dan satu. Semakin besar nilai $\mathrm{R}^{2}$ maka variabel-variabel independen memberikan hampir semua informasi yang dibutuhkan untuk memprediksi variasi variable dependen. Hasil regresi dari menunjukan nilai $\mathrm{R}^{2}$ sebesar 0.684 . Ini berarti bahwa sebasar $68,4 \%$ variasi ketimpangan distribusi pendapatan di Provinsi Sulawesi Selatan dapat dijelaskan dari variasi ke lima variabel independen yaitu Desentralisasi Fiskal (DF), Aglomerasi (AG), Tingkat Pengganguran Terbuka (TPT), Indeks Pembangunan Manusia (IPM) dan Jumlah Penduduk (NP).

b. Uji Signifikansi Simultan (Uji F)

Uji $\mathrm{F}$ digunakan untuk melihat pengaruh variabel-variabel independen terhadap variabel dependen secara keseluruhan. Apabila nilai $F$ hitung lebih besar dari nilai $F$ tabel atau probabilitas $\mathrm{F}$ lebih kecil dari $5 \%(\mathrm{a}=5 \%)$ maka variable variabel independen dalam model secara bersama-sama mempengaruhi variable dependen. Tabel 4.6 dapat dilihat bahwa nilai dari $\mathrm{F}$ hitung adalah 8.884 dengan probabilitas sebesar 0.000 lebih kecil dari alpha $5 \%(a=5 \%)$. Hal ini berarti variabel independen Desentralisasi Fiskal (DF), Aglomerasi (AG), Tingkat Pengganguran Terbuka (TPT), Indeks Pembangunan Manusia (IPM) dan Jumlah Penduduk (NP) dapat mempengaruhi secara signifikan variabel dependen ketimpangan distribusi pendapatan di Provinsi Sulawesi Selatan.

c. Pengujian Signifikasi Parameter Individual (Uji Statistik t)

Tabel 4 Estimasi Model

\begin{tabular}{lccll}
\hline \multicolumn{1}{c}{ Variabel } & Coef & Std. Error & t-Statistic & Prob. \\
\hline C & 16.110 & 39.238 & 0.411 & 0.682 \\
LOG(DF) & 0.419 & 0.358 & 1.170 & 0.244 \\
LOG(AG) & -0.083 & 4.313 & -0.019 & 0.985 \\
LOG(TPT) & 0.402 & 0.208 & 1.932 & 0.056 \\
LOG(IPM) & -23.477 & 7.306 & -3.213 & 0.002 \\
LOG(NP) & 6.122 & 3.000 & 2.041 & 0.044
\end{tabular}

Sumber: Lampiran Diolah, Tahun 2017

Berdasarkan hasil analisis pada tabel 4 estimasi model dengan metode fixed effect maka diperoleh hasil sebagai berikut:

1. Pengaruh Desentralisasi fiskal terhadap Disparitas distribusi Pendapatan 
Dari hasil regresi, diperoleh hasil bahwa desentralisasi berpengaruh positif dan tidak signifikan terhadap Disparitas pendapatan di Provinsi Sulawesi Selatan. Ini ditunjukan dengan nilai probabilitas sebesar 0.244 lebih besar dari alpha 5\%. Kenaikan 1 persen desentralisasi akan meningkatkan disparitas pendapatan di Provinsi Sulawesi Selatan sebesar 0.244 dengan asumsi aglomerasi, tingkat pengganguran terbuka, Indeks pembangunan manusia dan jumlah penduduk di anggap konstan, dimana kenaikan nilai desentralisasi fiskal akan mengakibatkan peningkatan pula terhadap disparitas pendapatan di Provinsi Sulawesi Selatan.

Menurut Akai dan Sakata (2005), desentralisasi fiskal merupakan sebagai alat yang digunakan untuk meningkatkan efisiensi sektor publik dan untuk mengurangi kesenjangan antar daerah. Akai dan Sakata (2005) menjelaskan pada sistem sentralistik pelaksaanaan untuk mendistribusikan sumber daya daerah yang kaya ke daerah yang miskin dan dapat mengurangi kesenjangan, tetapi pada sistem otonomi daerah bukan berarti dampak kesenjangan sosial lebih besar dibanding sistem sentralistik, dalam sistem otonomi diharapkan daerah akan lebih intensif untuk memajukan daerahnya dengan melakukan kebijakan-kebijakan untuk pembangunan ekonomi. Hal ini sejalan dengan penelitian yang dilakukan oleh Dewi Rosdiana yang berjudul pengaruh desentralisasi fiskal terhadap pertumbuhan ekonomi daerah dan ketimpangan, dimana desentralisasi berpengaruh positif terhadap ketimpangan.

2. Pengaruh Aglomerasi terhadap Disparitas Distribusi Pendapatan

Dari hasil regresi, diperoleh hasil bahwa aglomerasi berpengaruh negatif dan tidak signifikan terhadap Disparitas pendapatan di Provinsi Sulawesi Selatan. Ini ditunjukan dengan nilai probabilitas sebesar 0.985 lebih besar dari alpha 5\%. Kenaikan 1 persen aglomerasi akan meningkatkan disparitas pendapatan di Provinsi Sulawesi Selatan sebesar 0.083 dengan asumsi desentralisasi fiskal, tingkat pengganguran terbuka, Indeks Pembangunan Manusia dan jumlah penduduk di anggap konstan. Hal ini disebabkan karena terkonsentrasinya kegiatan produksi yang cukup tinggi di Sulawesi Selatan yang mendorong pertumbuhan daerah cenderung lebih cepat. Sedangkan bagi wilayah lain yang memiliki konsentrasi kegiatan produksi rendah akan mendorong pengangguran dan rendahnya tingkat pendapatan masyarakat setempat. Oleh karena itu, aglomerasi mendorong semakin tingginya ketimpangan wilayah.

Sjafrizal (2008), mengatakan terjadinya konsentrasi kegiatan ekonomi yang cukup tinggi pada wilayah tertentu jelas akan mempengaruhi ketimpangan pembangunan antar wilayah. Konsentrasi ekonomi ini tercermin dalam kegiatan aglomerasi. Pertumbuhan 
ekonomi daerah akan cendeung lebih cepat pada daerah dimana terdapat konsentrasi kegiatan ekonomi yang cukup besar. Lebih lanjut, Perroux mengatakan bahwa, ditinjau dari aspek lokasinya pembangunan ekonomi di daerah tidak merata dan cenderung terjadi proses aglomerasi (pemusatan) pada pusat-pusat pertumbuhan. Pada nantinya pusatpusat pertumbuhan tersebut akan mempengaruhi daerah yang lambat perkembangnnya, terjadinya aglomerasi tersebut memiliki manfaat-manfaat tertentu yaitu keunggulan secara ekonomis (usaha dalam jumlah besar) dan keuntungan penghematan biaya.

3. Pengaruh Tingkat Pengangguran Terbuka terhadap Disparitas Distribusi Pendapatan

Dari hasil regresi, diperoleh hasil bahwa tingkat pengangguran terbuka berpengaruh positif dan signifikan terhadap Disparitas pendapatan di Provinsi Sulawesi Selatan. Ini ditunjukan dengan nilai probabilitas sebesar 0.056 lebih kecil dari alpha 10\%. Kenaikan 1 persen tingkat pengangguran terbuka akan menaikkan disparitas pendapatan di Provinsi Sulawesi Selatan sebesar 0.402 dengan asumsi desentralisasi fiskal, aglomerasi, Indeks pembangunan manusia dan jumlah penduduk di anggap konstan.

Penelitian ini, sejalan dengan hasil penelitian Ulfie (2014) dimana pengangguran berpengaruh positif, dalam penelitiannya menjelaskan bahwa upah merupakan salah satu komponen dalam penghitungan pendapatan nasional. Apabila tingkat pengangguran semakin tinggi, maka nilai komponen upah akan semakin kecil. Dengan demikian, nilai pendapatan nasional pun akan semakin kecil dan akan berdampak pada ketimpangan setiap daerahnya. Sejalan pula dengan hasil penelitian yang dilakukan oleh Cysne, Rubens Penha (2004) bahwa tingkat pengangguran memiliki hubungan positif terhadap tingkat kesenjangan pendapatan.

Upah merupakan salah satu komponen dalam penghitungan pendapatan nasional. Apabila tingkat pengangguran semakin tinggi, maka nilai komponen upah akan semakin kecil. Dengan demikian, nilai pendapatan nasional pun akan semakin kecil. Oleh karena itu, nilai pendapatan nasional yang semakin kecil akibat pengangguran akan menurunkan nilai pendapatan perkapita juga. Atau dapat juga dikatakan, orang yang menganggur berarti tidak memiliki penghasilan, sehingga hidupnya pun akan membebani orang lain yang bekerja. Hal ini pun mengakibatkan terjadinya penurunan pendapatan perkapita. Dengan kata lain, apabila tingkat pengangguran di suatu daerah tinggi, maka pendapatan perkapita akan menurun. Dan sebaliknya, apabila tingkat pengangguran rendah, maka pendapatan per kapita akan meningkat, yang dapat menurunkan tingkat kesenjangan pendapatan di suatu daerah pula. 
Samsir, Rahman, Menelusur Ketimpangan Distirbusi Pendapatan Kabupaten dan Kota.

Akan tetapi, tingkat pengangguran harus terus diminimalisir. Untuk mengatasi masalah pengangguran yang nantinya akan berdampak pada tingkat kesenjangan pendapatan ini, dapat dilakukan beberapa cara, di antara lain: mendorong majunya pendidikan, meningkatkan latihan kerja untuk memenuhi kebutuhan keterampilan, meningkatkan dan mendorong kewiraswastaan, mendorong terbukanya kesempatan usahausaha informal, meningkatkan usaha transmigrasi, meningkatkan pembangunan dengan sistem padat karya, serta membuka kesempatan untuk bekerja keluar negeri.

4. Pengaruh Indeks Pembangunan Manusia terhadap Disparitas Distribusi Pendapatan

Dari hasil regresi, diperoleh hasil bahwa indeks pembangunan manusia berpengaruh negative dan signifikan terhadap Disparitas pendapatan di Provinsi Sulawesi Selatan. Ini ditunjukan dengan nilai probabilitas sebesar 0.002 lebih kecil dari alpha 5\%. Kenaikan 1 persen indeks pembangunan manusia akan meningkatkan disparitas pendapatan di Provinsi Sulawesi Selatan sebesar 23.477 dengan asumsi desentralisasi fiskal, aglomerasi, tingkat pengangguran terbuka dan jumlah penduduk di anggap konstan.

Hal ini sesuai dengan hasil penelitian yang dilakukan oleh Alvan, Arzu 2007) yang mengatakan bahwa indeks pembangunan manusia berpengaruh negatif terhadap tingkat kesenjangan pendapatan. Hal ini pun sesuai dengan hipotesis yang menyatakan bahwa,"Diduga variabel indeks pembangunan manusia berpengaruh negatif terhadap kesenjangan pendapatan antar kabupaten/kota di Provinsi Jawa Timur di era desentralisasi fiskal."

Menurut UNDP (2004), pembangunan manusia berpusat pada manusia, yang menempatkan manusia sebagai tujuan akhir dari pembangunan nasional dan bukan sebagai alat dari pembangunan. Berbeda dengan konsep pembangunan yang memberikan perhatian utama pada pertumbuhan ekonomi dengan asumsi bahwa pertumbuhan ekonomi pada akhirnya akan menguntungkan manusia. Pembangunan manusia ini mencakup semua pilihan yang dimiliki manusia di semua golongan masyarakat pada semua tahap pembangunan dengan lebih luas dan lebih komprehensif.

Tujuan utama dari pembangunan manusia ini adalah untuk memperbanyak pilihanpilihan yang dimiliki manusia, dimana hal tersebut tidak mungkin tercapai tanpa adanya kebebasan memilih apa yang mereka inginkan dan bagaimana mereka akan menjalani hidup. Indeks Pembangunan Manusia (IPM) ini pun terbagi dalam tiga dimensi, yakni angka harapan hidup, tingkat pendidikan yang diukur dari lamanya rata-rata penduduk bersekolah dan angka melek huruf, serta purchasing power parity index (PPP). Oleh karena itu, semakin baik nilai Indeks Pembangunan Manusia (IPM), tingkat kesenjangan pendapatan daerah pun 
semakin rendah. Dan sebaliknya, semakin rendah nilai Indeks Pembangunan Manusia (IPM), maka dapat mengakibatkan tingkat kesenjangan pendapatan yang semakin tinggi.

Seperti dalam penelitian Alvan, Arzu (2007) yang mengatakan bahwa untuk mencapai GDP dan pendapatan perkapita yang lebih tinggi, serta tingkat kesenjangan yang lebih rendah, indeks pembangunan manusia sebaiknya diprioritaskan dalam program pembangunan suatu negara maupun daerah. Tingginya nilai indeks pembangunan manusia ini akan berdampak positif terhadap distribusi pendapatan, sehingga semakin baik nilai indeks pembangunan manusia, maka semakin rendah tingkat kesenjangan pendapatan suatu daerah. Begitu pula sebaliknya, semakin buruk nilai indeks pembangunan manusianya, maka semakin tinggi pula tingkat kesenjangan pendapatannya. Oleh karena itu, untuk menekan tingkat kesenjangan pendapatan di suatu daerah maupun negara, indeks pembangunan manusianya turut perlu dimaksimalkan.

5. Pengaruh Jumlah Penduduk terhadap Disparitas Pendapatan

Dari hasil regresi, diperoleh hasil bahwa jumlah penduduk berpengaruh positif dan signifikan terhadap disparitas pendapatan di Provinsi Sulawesi Selatan. Ini ditunjukan dengan nilai probabilitas sebesar 0.002 lebih kecil dari alpha 5\%. Kenaikan 1 jiwa penduduk akan meningkatkan disparitas pendapatan di Provinsi Sulawesi Selatan sebesar 6.122 dengan asumsi desentralisasi fiskal, aglomerasi, tingkat pengangguran terbuka dan indeks pembangunan manusiadi anggap konstan.

Berarti peningkatan jumlah penduduk signifikan mempengaruhi disparitas distribusi pendapatan kabupaten/kota Provinsi Sulawesi Selatan. Makah al ini menjadi kurang baik, karena hal tersebut dapat menambah tingkat pengangguran. Sehingga akan kesejahteraan masyarakat tidak akan tercapai.

\section{KESIMPULAN / CONCLUSION}

Berdasarkan hasil pengujian dan pembahasan mengenai disparitas distribusi pendapatan antar kabupaten/kota di Provinsi Sulawesi Selatan, maka dapat ditarik beberapa kesimpulan. Selama periode penelitian 2010-2015, terjadi ketimpangan pembangunan yang tidak cukup signifikan berdasarkan Indeks Williamson, sedangkan menurut Indeks entropi Theil, ketimpangan pembangunan boleh dikatakan kecil yang berarti masih terjadinya pemerataan pembangunan setiap tahunnya selama periode pengamatan. Sebagai akibatnya tidak terbuktinya hipotesis Kuznets di Kabupaten/kota Provinsi Sulawesi Selatan yang mengatakan adanya kurva $U$ terbalik. Variabel desentralisasi fiskal (X1), Aglomerasi (X2), Tingkat 
Pengangguran Terbuka (X3), Indeks Pembangunan Manusia (X4), dan Jumlah Penduduk (X5) secara simultan atau bersama-sama berpengaruh terhadap disparitas distribusi pendapatan (RD) antar kabupaten/kota di Provinsi Sulawesi Selatan.

Desentralisasi fiskal (X1) dan Aglomerasi (X2) tidak berpengaruh signifikan, sedangkan Tingkat Pengangguran Terbuka (X3), Indeks Pembangunan Manusia (X4), dan Jumlah Penduduk (X5) berpengaruh signifikan terhadap disparitas distribusi pendapatan (RD) antar kabupaten/kota di Provinsi Sulawesi Selatan. Dengan demikian, saran bagi pemerintah agar secara serius untuk mengatasi pemerataaan pembangunan dan PDRB per kapita penduduk di kabupaten atau daerah yang ada.

\section{DAFTAR PUSTAKA / REFERENCES}

Adi, Priyo Hari. " Dampak Desentralisasi Fiskal Terhadap Pertumbuhsn Ekonomi Studi pada Kabupaten dan Kota se Jawa-Bali." Jurnal Interdisipliner Kriris UKSW. Diakses tanggal 1 November 2016, dari http://priyohari.files.wordpress.com

Akai, Nobuo dan Masayo Sakata. 2005. Fiscal Decentralization, Commitment, and Regional Inequality: Evidence fram Statel-level Cross-sectional Data for the United States. CIRJE-F-315. Diakses dari http://www.e.utokyo.ac.jp/cirje/research/03research02dp.html pada 7 September 2016.

Alvan, Arzu. Forging a Link Between Human Development and Income Inequality: CrossCountry Evidence. Review of Social, Economic and Business Studies, Vol.7/8, 3143. 2007.

Arsyad, Lincolin. 2004. Ekonomi Pembangunan Edisi Keempat . Yogyakarta: STIE YKPN

Arsyad, Lincolin. 2010. Pengantar Perencanaan dan Pembangunan Ekonomi Daerah. Yogyakarta : BPFE-Yogyakarta.

Astuti D R, 2015. Analisis Determinan Ketimpangan Distribusi Pendapatan Di Daerah Istimewa Yogyakarta Periode 2005-2013 Bahl, Roy W. and Sally Wallace,2001, Fiscal Decentralization: The Provincial-Local Dimension. Fiscal Policy training Program 2001. Fiscal Decentralization Course. July 23-Agust, 2001. AtlantaGeorgia. World Bank Institute and Georgia State University, Andrew Young School of Policy Studies.

Bahl, Roy W.,2000. China : Evaluating the impact of Intergovemmental Fiscal reform dalam Fiscal Decentralization in Developing Countries. Edited by Richard M. Bird and Francois Vaillancourt, United Kingdom : Cambridge Univercity Press.

Barzelay, M.1991."Managing Local Development, Lesson from Spain". Policy Sciences, 24, $271-290$. 
Badan Pusat Statistik, Berbagai Penerbitan. Sulawesi Selatan Dalam Angka, BPS Makassar

Badan Pusat Statistik, Berbagai Penerbitan. Keadaan Angkatan Kerja, BPS Makassar

Badan Pusat Statistik, Berbagai Penerbitan, Tinjauan PDRB Kabupaten/Kota Sulawesi Selatan, BPS Makassar

Bonet, Jaime. 2006. Fiscal Decentralization and Regional Income Disparities: Evidence from The Colombian Experience. Ann Reg Sci 40:661-676. http://www.springerlink.com/content/36595348343m6660/fulltext.pdf . Diakses tanggal 15 November 2016.

Dumairy. 1996. Perekonomian Indonesia. Erlangga, Jakarta.

Cysne, Rubens Penha. 2004. On the Positive Correlation Between Income Inequality and Unemployment. Fundacao Getulio Vargas - Escola de Pos-Graduacao em Economia

Efriza, Ulfie. Analisis Kesenjangan Pendapatan Antar Kabupaten/Kota di Provinsi Jawa Timur di Era Desentralisasi Fiskal. 2014. Jurnal Universitas Brawijaya Malang.

Glaeser EL. 2006. Inequality.Barry R Weingast BR, Wittman DA, editor.The Oxford Handbook of Political Economy: Oxford University Press Inc.New York.

Hajiji, 2010. Pertumbuhan Ekonomi, Ketidakmerataan Pendapatan Dan Pengentasan Kemiskinan Di Provinsi Riau Tahun 2002-2008 (Tesis): Bogor: Sekolah Pascasarjana Institut Pertanian Bogor.

Hessel Nogi S. 2007. Manajemen Publik. Jakarta: PT Gramedia.

Irawan, M. Suparmoko.2002. Ekonomika Pembangunan Edisi ke 6. Yogyakarta: BFE.

Joko Tri Handoyo. 2015. Desentralisasi Fiskal Seutuhnya. Diakses dari http://www.kemenkeu.go.id/en/node/46912 pada 7 September 2016.

Jhingan , M.L. 2003. Ekonomi Pembangunan dan Perencanaan . Jakarta : PT Raja Grafindo Persada.

Kementrian Keuangan. 2010. Grand Design Desentralisasi Fiskal di Indonesia. Diakses dari http://www.djpk.kemenkeu.go.id/attachments/article/186/GrandDesignFD2.pdf pada 11 September 2016.

Kuncoro, Mudrajad. 2002. Analisis Spasial dan regional: Studi Aglomerasi dan Kluster Industri Indonesia. UPP AMP YKPN: Yogyakarta.

Kuncoro, Mudrajad. 2004. Otonomi dan Pembangunan Daerah. Jakarta: Erlangga.

Kuncoro, Mudrajad. 2006. Ekonomika Pembangunan:Teori, Masalah, dan Kebijakan Edisi Keempat. Yogyakarta : UPP STIM YKPN 
Kuncoro, Mudrajad. 2010. Masalah, Kebijakan, dan Politik Ekonomika Pembangunan. Jakarta : Erlangga

Rahayu S, 2000. Analisa Pemerataan Pendapatan Usaha ternak Sapi Perah Rakyat (Survey Pada Peternakan Sapi Perah Rakyat di KUD Mitra Yasa Kabupaten Tasikmalaya). Fakultas Peternakan, Universitas Padjadjaran. Sumedang.

Robinson. 2004. Ekonomi Regional: Teori dan Aplikasi. Bumi Aksara. Jakarta.

RM. Riadi. 2012 Pertumbuhan dan Ketimpangan Pembangunan Ekonomi Antar Daerah di Provinsi Riau. Diakses tanggal 17 September 2016. Darihttp://rmriadi.yolasite.com/resources/Jurnal\%20Pertumbuhan\%20dan\%20Ket impangan.pdf

Sasana, Hadi. 2009. Peran Desentralisasi Fiskal Terhadap Kinerja Ekonomi Di Kabupaten/Kota Provinsi Jawa Tengah". Jurnal Ekonomi Pembangunan Volume 10, Nomor 1. Universitas Diponegoro.

Simonsen Sianturi. 2011. Dampak Desentralisasi Fiskal Terhadap Ketimpangan Pendapatan Antar Wilayah (Studi Kasus Kabupaten/Kota Propinsi Sumatera Utara). diakses dari http://eprints.undip.ac.id/29289/1/Jurnal.pdf pada 9 September 2016.

Sjafrizal. 2008. Ekonomi Regional Teori dan Aplikasi. Baduose Media. Padang Sumatera Barat.

Sjafrizal. 2012. Ekonomi Wilayah dan Perkotaan. Jakarta: PT Raja Grafindo Persada.

Sugiyono. 2013. Metode Penelitian Pendidikan: Pendekatan Kuantitatif, Kualitatif, dan R\&D. Bandung: CV. Alfabeta.

Tarigan, Robinson. 2005. Ekonomi Regional: Teori dan Aplikasi. Bumi Aksara. Jakarta.

Todaro, Michael P. 2003 Pembangunan Ekonomi di Dunia Ketiga. Erlangga, Jakarta

Todaro, Michael P. dan Stephen C. Smith. 2006. Pembangunan Ekonomi: Jilid 1. Jakarta: Erlangga.

Tulus T.H. Tambunan. 2011. Perekonomian Indonesia: Kaian Teoritis dan Analisis Empiris. Bogor: Ghalia Indonesia.

Waluyo, Joko. 2007. " Dampak Desentralisasi Fiskal terhadap Pertumbuhan Ekonomi dan Ketimpangan Pendapatan Antardaerah di Indonesia". Parallel Session IA : Fiskal Decentralization, Wisma Makara kampus UI -Depok,12 Desember 1999. 
